\title{
Yields, Nutrient Quality, and Palatability to Sheep of Fourteen Grass Accessions for Poten- tial Use on Sagebrush-Grass Range in Southeastern Idaho
}

\author{
ROBERT B. MURRAY
}

\section{Abstract}

Fourteen grass accessions were evaluated in terms of yields, nutrient quality, and palatability to sheep at the U.S. Sheep Experiment Station in southeastern Idaho. The interspecific hybrid (Agropyron cristatum $\times A$. desertorum) produced the greatest amount of total biomass (which includes leaves, stems, and heads), but Russian wildryes (Psathrostachys juncea), tall fescue (Festuca arundinacea), and the RS- hybrid (Elytrigia repens $\times E$. spicata) produced a greater proportion of leaf material.

Crude protein contents declined with advance in plant maturity in all accessions, except $R$ ussian wildryes (Bozoisky-Select and RWR-V13) in which crude protein contents declined only slightly between June 30 and September 15 . All accessions contained adequate $\mathrm{Ca}, \mathrm{Mg}$, and $\mathrm{Mn}$ levels in the forage throughout the spring, summer and fall. Phosphorus and $\mathrm{Zn}$ levels were inadequate for sheep during late summer and fall. Sulfur content was below recommended levels for sheep. Potassium levels dropped below recommended rates in some accessions on September 15, and certain accessions indicated a proneness towards inducing grass tetany in early spring based on $\mathrm{K}:(\mathrm{Ca}+\mathrm{Mg})$ ratios. Copper levels were adequate for sheep on June 30 , but 10 of 14 accessions were below recommended levels on September 15 .

When preference is considered without interference from seedstalks, all accessions were preferred similarly by sheep. However, preference decreased as numbers of seedstalks increased. Burning in mid-March removed dead standing seedstalks and litter providing more accessible forage, but tended to aggravate the problem by increasing the number of new seedstalks. Heavy use in the spring may reduce flowering, and produce a greater proportion of vegetative stems.

An index based on leaf yields, crude protein content, and sheep preference was used to rank species. This index ranked the Russian wildrye (Bozoisky-Select) first followed by RWR-V13 second.

Evaluating the performance of new grass cultivars and species under a variety of environmental conditions is very important in order to develop recommendations for their use. Species such as the crested wheatgrass ("Fairway", Agropyron cristatum and "Standard", A. desertorum) and Russian wildrye (Psathrostachys juncea) ${ }^{1}$ have been used extensively on semiarid ranges for grazing, erosion control, and roadside stabilization. In Canada, Lodge et al. (1972) reported that some 800 thousand ha had been planted to

\footnotetext{
The author is range scientist, USDA-ARS, located at the U.S. Sheep Experiment Station, Dubois, Idaho 83423 . The facility is maintained in cooperation with the University of Idaho.

The author wishes to thank Dr. Kay H. Asay, USDA-ARS, Crops Research Laboratory, Logan, Utah, for providing seed and technical information relative to the accessions; Dr. Henry F. Mayland and staff, USDA-ARS, Snake River Conservation Research center, Kimberly, Ida., for providing laboratory assistance.

Manuscript received October 18, 1983.
}

Nomenclature follows that proposed by Dr. D.R. Dewey, Crops Research Lahoratory, Logan, Utah. (Dewey, D.R. 1983. Historical and current taxonomic perspectives of Agropyron, Elymus, and related genera. Crop Sci. 23:637-642.) crested wheatgrass, while Dewey and Asay (1975) estimated that 5 million ha have been planted in the western United States. In Idaho alone some 650 thousand ha of public land (BLM document, 1974) and an additional 200 thousand ha of private land (Dr. Lee Sharp, quoted in Reynolds and Trost 1980) have been planted to crested wheatgrass. Although seeding acreages for Russian wildrye do not appear available, Drawe and Palmblad (1977) indicate that the species is widely distributed over the Northern Great Plains and Intermountain areas. Such extensive use is based on their value determined through performance testing and research.

The value of crested wheatgrass, in a grazing context, is that it can be used to provide earlier feed, while deferring use of native pastures (Sarvis 1941, Lodge 1963, and Smoliak 1968). Russian wildrye often provides more nutritious feed during summer and fall compared to native range (Rogler and Lorenz 1970). In Canada, Smoliak and Slen (1974) have shown that both crested wheatgrass and Russian wildrye are effective in reducing the acreage requirement and extending the grazing season when used in conjunction with native pastures. While these species have proven their value, research is in progress to further improve grass species for use on semiarid rangelands through selection and hybridization within and between species.

Scientists at the Crops Research Laboratory 2 at Logan, Utah are actively breeding superior strains of wheatgrasses, wildryes, and promising interspecific hybrids, and evaluating their performance under a variety of climates and sites. This study, one part of the effort, reports on the performance of some standard commercial source material and new selections outplanted at the U.S. Sheep Experiment Station. The information presented is useful for comparing the adaptability, productivity, quality, and palatability to sheep of the various accessions with performance at other sites and with other selections.

\section{Study Area and Methods}

The study area is located in a sagebrush-grass site characteristic of the Upper Snake River Plains in southeastern Idaho, approximately $85 \mathrm{~km}$ north of Idaho Falls. Prior to site preparation, the vegetation consisted primarily of threetip sagebrush (Artemisia tripartita), bluebunch wheatgrass (Elytrigia spicata)', and Nevada bluegrass (Poa nevadensis). The soil is considered to be in the tentative Jacoby Soil Series, a Typic Haplustoll, a member of a fine loamy, mixed, frigid family. The soil textures of the A1 and B2 horizons are loams. Below $28 \mathrm{~cm}$ the $\mathrm{C} 1$ and $\mathrm{C} 2$ horizons are loams and fine sandy loams, and are moderately to strongly calcareous, respectively.

During August 1977, the study area was plowed to a depth of approximately $30 \mathrm{~cm}$, harrowed, and disked to remove competing

${ }^{2}$ A facility of the USDA-ARS located on campus in cooperation with the Utah State University. 
vegetation. During late October and early November 1977,14 grass accessions were hand-seeded into 13 rows within a plot $6.1 \times$ $6.1 \mathrm{~m}$ at rates shown in Table 1. Each accession was replicated 3 times.

Table 1. Fourteen grass accessions, their characteriatics and seeding rate outplanted at the U.S. Sheep Experiment Station.

\begin{tabular}{|c|c|c|}
\hline Accessions & Characteristics & $\begin{array}{l}\text { Seeding } \\
\text { rate } \\
\mathrm{kg} / \mathrm{ha}\end{array}$ \\
\hline $\begin{array}{l}\text { Crested wheatgrass or } \\
\text { CWG Hybrid }\end{array}$ & $\begin{array}{l}\text { Hybrid between induced tetraploid } A \text {. } \\
\text { cristatum (Cultivar Fairway) and } \\
\text { natural tetraploid } A \text {. desertorum }\end{array}$ & 9.6 \\
\hline CWG - (V6-7) & Selection from cultivar Nordan & 11.0 \\
\hline Fairway & Diploid A. cristatum & 10.8 \\
\hline Siberian WG & Selection from $A$. fragile & 12.3 \\
\hline CWG - 163 & $\begin{array}{l}\text { Selection of } A . \text { cristatum from } \\
\text { Turkey }\end{array}$ & 12.6 \\
\hline Fairway - I28 & $\begin{array}{l}\text { Induced tetraploid of } A \text {. cristatum } \\
\text { (cultivar Fairway). Is } \# 3 \text { with doubled } \\
\text { chromosome number and is also one } \\
\text { of the original parents of } \# 1 \text {. }\end{array}$ & 11.3 \\
\hline RS Hybrid & $\begin{array}{l}F_{6} \text { generation of the Elytrigia repens } \\
\times E \text {. spicata hybrid }\end{array}$ & 12.9 \\
\hline Nordan & Cultivar of $A$. desertorum & 10.8 \\
\hline CWG - (M34-38) & Selection of $A$. desertorum & 12.3 \\
\hline CWG - R & A. cristatum from Iran & 13.4 \\
\hline Tall Fescue & Festuca arundinacea & 13.4 \\
\hline Bozoisky - Select & $\begin{array}{l}\text { Selection from cultivar Bozoisky of } \\
\text { Psathyrostachys juncea }\end{array}$ & 10.5 \\
\hline RWR - V13 & $\begin{array}{l}\text { Selection from USDA-SCS strain } \\
\text { P210 of } P \text {. juncea }\end{array}$ & 10.8 \\
\hline RWR - I28 & $\begin{array}{l}\text { Induced tetraploid of } P \text {. juncea from } \\
\text { University of Idaho }\end{array}$ & 13.4 \\
\hline
\end{tabular}

Observations of germination were begun in early April 1978. In mid-May 1978 the number of emerged plants contained in $15.2 \mathrm{~cm}$ of 6 rows per plot were counted. The locations were randomly selected. Yields were determined during late June and midSeptember in 1978 and 1979 by harvesting a strip $30 \mathrm{~cm}$ wide to a 1-cm stubble height across 10 rows of each plot, air-drying (18-27 C) and weighing to the nearest gram. The leaf blades were separated from stems and were ground to pass a 40-mesh screen for chemical analysis. Inadvertently, the 2 fractions were not weighed. However, in late August, 1983, $61 \mathrm{~cm}$, randomly selected, of one row in each replication was harvested and separated into leaf blade and seedstalk fractions to determine the percentage of leaf material.

Nitrogen was determined by standard micro-Kjeldahl procedures and is reported as percent crude protein $(\% \mathrm{~N} \times 6.25)$ (Bremner 1965). Phosphorus, sulfur, calcium, magnesium, potassium, copper, manganese, and zinc contents were determined on 2:1 nitric acid:perchloric acid digests (Greweling 1976). Phosphorus was determined by the ammonium metavanadate-ammonium molybdate procedure (Greweling 1976). Sulfur was determined turbidimetrically, while $\mathrm{Ca}, \mathrm{Mg}, \mathrm{K}, \mathrm{Na}, \mathrm{Zn}, \mathrm{Mn}$, and $\mathrm{Cu}$ were determined by atomic absorption spectroscopy.

Sheep preference for the 14 different grasses was determined in mid-May, Mid-July, and mid-September, 1980, by allowing sheep free-access to all plots and then rating the degree of use. Ewes and some rams were grazed for 7 days between $5 / 6-5 / 14$, for 5 days between $7 / 9-7 / 13$, and for 8 days between $9 / 8-9 / 15$. At each date the stocking rates were 56,105 , and 79 sheep-days per ha, respectively. The amount of utilization and amount of seedstalks were rated on each plot by 3-4 individuals using a scale of $0-10$; where 10 represented the maximum amount of use or maximum number of seedstalks. Initially all plots were visually examined to determine the plot which appeared to be grazed the heaviest or had the most seedstalks. Then, all other plots were compared to the maximum and rated accordingly.

On March 20,1981, approximately one-third of each plot was burned to remove accumulated seedstalks to improve accessibility and use by sheep. Counts of seedstalks in burned and nonburned portions were made in late July, 1981, to determine whether burning would reduce the incidence of seedstalks.

An index was computed to compare the accessions in terms of their overall value. This index was the sum of the percent of the largest leaf yield on July 3,1979 , percent of the largest leaf crude protein contents (June 30 and September 15, 1978), and the percent of the greatest rated used (May 14+ July 14 + September 15, 1980). The highest obtainable index was 300 .

\section{Results and Discussion}

Seed was planted at varying rates between accessions, because of the limited availability of some seed lots (Table 1). Originally, the plan was to seed at $13.4 \mathrm{~kg} / \mathrm{ha}$ to achieve a fully stocked stand. However, it was subsequently found that the number of emerging plants was not related to the seeding rate, and the yield data suggest that most accessions could produce satisfactory stands at seeding rates as low as $9.0 \mathrm{~kg} / \mathrm{ha}$.

\section{Germination and Emergence}

By mid-April 1978, the following accessions had germinated in at least 1 of each of the 3 replications: CWG-I63 (Fairway), CWGHybrid, CWG-(V6-7), Siberian WG, and RS Hybrid. By May 2 all accessions in all plots had germinated. Precipitation was nearly 4 times above average in April, 1978, and temperatures were about normal (Table 2), which may have contributed to the successful

Table 2. Precipitation, mean maximum and mean minimum temperatures for the study period (1978-1980) and for long-term averages (1924 and 1933-1980). The weather data recorded at the U.S. Sheep Experiment Station headquarters, Dubois, Idaho approximately $2 \mathrm{~km}$ from study site.

\begin{tabular}{|c|c|c|c|c|c|c|c|c|}
\hline Period & Apr & May & Jun & Jul & Aug & Sep & Oct & $\begin{array}{l}\text { Mean } \\
\text { Annual }\end{array}$ \\
\hline \multicolumn{9}{|c|}{ Precipitation, $\mathrm{mm}$} \\
\hline 1978 & 82 & 7 & 11 & 22 & 2 & 51 & 6 & 275 \\
\hline 1979 & 3 & 15 & 19 & 31 & 39 & 6 & 21 & 229 \\
\hline 1980 & 10 & 114 & 38 & 26 & 25 & 45 & 17 & 368 \\
\hline $1924-1980$ & 22 & 37 & 45 & 20 & 23 & 23 & 21 & 288 \\
\hline \multicolumn{9}{|c|}{ Maximum Temperature, deg. C. } \\
\hline 1978 & 11.2 & 17.0 & 24.3 & 28.9 & 27.2 & 20.7 & 16.8 & 12.2 \\
\hline 1979 & 11.2 & 19.1 & 25.3 & 29.9 & 27.8 & 26.4 & 15.9 & 12.9 \\
\hline 1980 & 14.9 & 16.6 & 21.7 & 28.4 & 26.1 & 21.8 & 14.7 & 12.9 \\
\hline $1933-1980$ & 11.9 & 18.2 & 23.0 & 29.5 & 28.4 & 22.4 & 14.7 & 12.5 \\
\hline \multicolumn{9}{|c|}{ Minimum Temperature, deg. $\mathrm{C}$} \\
\hline 1978 & -0.3 & 2.8 & 7.9 & 11.3 & 9.8 & 5.3 & 0.4 & -0.7 \\
\hline 1979 & -2.1 & 3.9 & 7.3 & 11.3 & 10.6 & 6.9 & 1.4 & -0.9 \\
\hline 1980 & 0.7 & 4.1 & 7.3 & 11.2 & 10.7 & 6.3 & 0.8 & 0.5 \\
\hline $1933-1980$ & -1.3 & 3.6 & 7.4 & 11.6 & 10.5 & 5.7 & 0.9 & -0.5 \\
\hline
\end{tabular}

germination. Below-average precipitation in April, 1979, may have reduced germination, had the seed been planted in the fall 1978 or in spring 1979.

A maximum of $92 \mathrm{CWG}-163$ plants emerged per meter of row, while a minimum of $22 \mathrm{CWG}$ (V6-7) plants emerged per meter of row (Table 3). The yields on June 30, 1978, of the 9 Agropyron accessions and 1 Elytrigia accession were related to the number of emerging plants. simple linear equation $(Y=210+4.05 X)$ was not 
Table 3. Emergence, mean total yields and standard errors by dates in 1978 and 1979 , mean total yields over four dates, and numbers of seedatalks for 14 accessions outplanted at the U.S. Sheep Experiment Station, Dubois, Idaho.

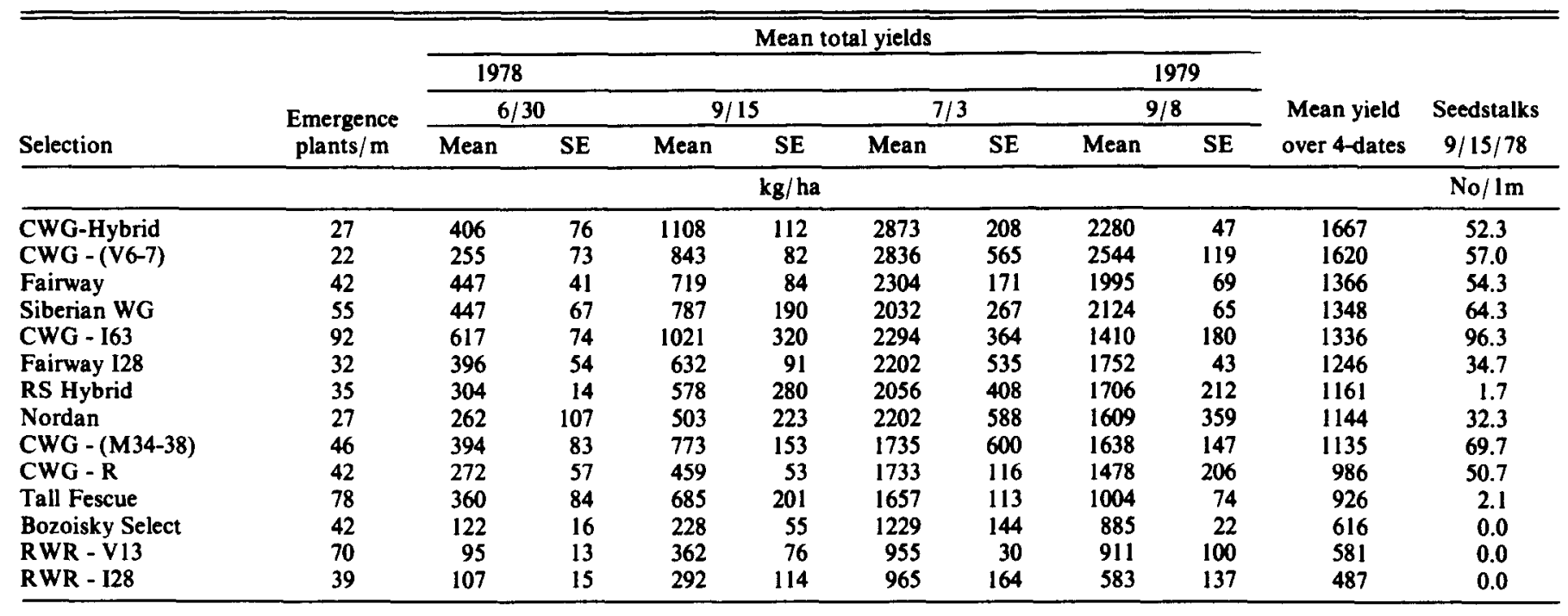

significantly related the number of emerging plants $(X)$ to yields $(\mathrm{Y})$, and only explained $42.3 \%$ of the variation. From a practical standpoint, the number of plants emerging is not a useful way to predict subsequent yields or to predict the success of the seeding. Environmental conditions and competition between plants within the row ultimately determine the character of the seeding.

\section{Total and Leaf Yields}

The CWG-hybrid produced the greatest total biomass (leaves, stems, and heads) and RWR-I28 the least, based on the average yields over the 4 harvest dates (Table 3 ). Although, the RS hybrid was ranked seventh in total biomass, nearly all the biomass was contained in the leaf fraction compared to the other wheatgrass accessions. The leaf fraction also contributed the most biomass in the tall fescue and Russian wildrye accessions.

\section{Crude Protein Contents}

All accessions had leaf crude protein contents greater than $11.4 \%$ on June 30 (Table 4). Of the wheatgrasses Nordan had the highest protein content at $16.7 \%$, and the RS-hybrid had the lowest content at $11.5 \%$. Perez-Trejo et al. (1979) found a very sharp drop in crude protein content of the RS hybrid between May 15 and June 15 , from 26.1 to $13.4 \%$, respectively. Although these values appear to be low, the June $\mathbf{3 0}$ harvest date is near the end of the growing season and plants are becoming dormant. BozoiskySelect had the highest crude protein content of any accession at $17.6 \%$ at this June date.

By mid-September leaf crude protein contents averaged $7.4 \%$ for the wheatgrasses, $11.3 \%$ for the Russian wildrye accessions, and $8.4 \%$ for tall fescue. Bozoisky-Select and RWR-V13 maintained relatively high leaf crude protein contents of 13.2 and $12.6 \%$, respectively. Between September 1 and September 15, 1978, the site received $36 \mathrm{~mm}$ of precipitation, which may have been sufficient to initiate new growth in some species and thus increase crude protein contents. However, the RS hybrid had only $7.3 \%$ crude protein content in this study, but Perez-Trejo (1979) found a large increase with fall regrowth.

According to the NRC-NAS $(1970,1975)$ crude protein requirements for cows nursing calves $(9.2 \% \mathrm{CP})$ and ewes suckling lambs (11.5\% CP) should be met by all accessions during the spring and early summer. Maintenance of dry pregnant mature cows $(5.9 \%$ CP) would be sustained by all accessions in late summer and fall, but ewe maintenance $(8.9 \% \mathrm{CP})$ may require some supplementation for sheep grazing on most accessions.

\section{Calcium, Magnesium, Phosphorus, and Ca:P Ratio}

Calcium percentages tended to increase with advance in plant maturity and were above the levels recommended by NRC-NAS $(1970,1975)$ for most accessions at both dates.

Magnesium contained in the forage decreased in the wheatgrasses, except for the RS-hybrid, which showed an increase. Magnesium also increased in the tall fescue and the 3 Russian wildrye accessions between June 30 and September 15. The increases may be associated with the tendency of Russian wildrye and tall fescue to remain greener for longer periods and their ability to renew growth sooner in response to fall precipitation. The levels of magnesium were considered adequate for both cattle and sheep during the spring through fall period.

On June 30 phosphorus percentages varied from a low of $0.24 \%$ in the CWG-hybrid and CWG-(M34-38) to a high of $0.32 \%$ in Fairway, CWG-R, and tall fescue. Phosphorus levels declined to a low of $0.08 \%$ in CWG-(M34-38) in mid-September. At the latter date phosphorus levels were well below those recommended for all classes of cattle and sheep as given in NRC-NAS $(1970,1975)$.

Once the basic requirement for calcium and phosphorus is met the ratio of $\mathrm{Ca}: \mathrm{P}$ is important. In normal circumstances the ratio should be less than $2: 1$, but can be as wide as $7: 1$ when sufficient vitamin $D$ is present (NRC-NAS, 1970). In most cases vitamin D is synthesized in the presence of adequate sunlight and retained by animals. All accessions had ratios less than 7:1, except for CWGI63 and CWG-(M34-38) on September 15.

\section{Sulfur and N:S Ratio}

Sulfur values were relatively low in all accessions at both dates, but were above or near levels of $0.1 \%$ recommended by the NRCNAS (1970) for cattle. The values were well below the 0.14-0.18\% for ewes and the $0.18-0.26 \%$ recommended for lambs (NRC-NAS, 1975). The levels declined with plant maturity, as expected, in all accessions except for Bozoisky-Select. This increase in Russian wildrye may be due to active growth occurring prior to the September 15 date.

For proper nitrogen utilization in the animal, the optimum ratio of N:S should be between 10:1 and 15:1 (Allaway, 1969). In these accessions the ratio was greater than 15:1 for the June 30 date and within the range for the September 15 date. Early in the season animals may have a reduced protein conversion efficiency and suffer nutritional problems if these accessions were the only source of forage. 
Table 4. Crude protein, mineral contents, and mineral ratios of leaves harvested in 1978 for 14 accessions outplanted at the U.S. Sheep Experiment Station, Dubois, Idaho.

\begin{tabular}{|c|c|c|c|c|c|c|c|c|c|c|c|c|c|}
\hline Accession & Date & $\begin{array}{l}\mathrm{CP} \\
\%\end{array}$ & $\begin{array}{l}\mathbf{P} \\
\%\end{array}$ & $\begin{array}{l}\mathbf{S} \\
\%\end{array}$ & $\begin{array}{l}\mathrm{Ca} \\
\%\end{array}$ & $\underset{\%}{\mathrm{Mg}}$ & $\begin{array}{l}\mathbf{K} \\
\%\end{array}$ & $\underset{\mathrm{ppm}}{\mathrm{Cu}}$ & $\begin{array}{l}\text { Mn } \\
\text { ppm }\end{array}$ & $\underset{\mathrm{ppm}}{\mathrm{Zn}}$ & Ca:P & $\mathrm{K}:(\mathrm{Ca}+\mathrm{Mg})$ & $\mathbf{N}: \mathbf{S}$ \\
\hline $\begin{array}{l}\text { Crested wheatgrass or CWG } \\
\text { Hybrid }\end{array}$ & $\begin{array}{l}\text { Jun } 30 \\
\text { Sep } 15\end{array}$ & $\begin{array}{r}13.4 \\
7.0\end{array}$ & $\begin{array}{l}.29 \\
.10\end{array}$ & $\begin{array}{l}.12 \\
.10\end{array}$ & $\begin{array}{l}.501 \\
.515\end{array}$ & $\begin{array}{l}.136 \\
.120\end{array}$ & $\begin{array}{r}2.24 \\
.69\end{array}$ & $\begin{array}{l}7 \\
7\end{array}$ & $\begin{array}{l}32 \\
32\end{array}$ & $\begin{array}{l}15 \\
12\end{array}$ & $\begin{array}{l}1.7 \\
5.2\end{array}$ & $\begin{array}{r}1.58 \\
.50\end{array}$ & $\begin{array}{l}17.8 \\
11.2\end{array}$ \\
\hline CWG-(V6-7) & $\begin{array}{l}\text { Jun } 30 \\
\text { Sep } 15\end{array}$ & $\begin{array}{r}15.7 \\
8.6\end{array}$ & $\begin{array}{l}.24 \\
.11\end{array}$ & $\begin{array}{l}.13 \\
.10\end{array}$ & $\begin{array}{l}.495 \\
.460\end{array}$ & $\begin{array}{l}.136 \\
.115\end{array}$ & $\begin{array}{r}1.93 \\
.82\end{array}$ & $\begin{array}{l}6 \\
3\end{array}$ & $\begin{array}{l}22 \\
37\end{array}$ & $\begin{array}{l}17 \\
14\end{array}$ & $\begin{array}{l}2.1 \\
5.8\end{array}$ & $\begin{array}{r}1.38 \\
.51\end{array}$ & $\begin{array}{l}19.3 \\
13.8\end{array}$ \\
\hline Fairway & $\begin{array}{l}\text { Jun } 30 \\
\text { Sep } 15\end{array}$ & $\begin{array}{r}14.6 \\
7.6\end{array}$ & $\begin{array}{l}.32 \\
.11\end{array}$ & $\begin{array}{l}.13 \\
.12\end{array}$ & $\begin{array}{l}.597 \\
.624\end{array}$ & $\begin{array}{l}.152 \\
.130\end{array}$ & $\begin{array}{r}1.94 \\
.65\end{array}$ & $\begin{array}{l}2 \\
5\end{array}$ & $\begin{array}{l}34 \\
54\end{array}$ & $\begin{array}{l}15 \\
13\end{array}$ & $\begin{array}{l}1.9 \\
5.7\end{array}$ & $\begin{array}{r}1.17 \\
.40\end{array}$ & $\begin{array}{l}18.0 \\
10.1\end{array}$ \\
\hline Siberian WG & $\begin{array}{l}\text { Jun } 30 \\
\text { Sep } 15\end{array}$ & $\begin{array}{r}13.8 \\
6.8\end{array}$ & $\begin{array}{l}.27 \\
.10\end{array}$ & $\begin{array}{l}.15 \\
.10\end{array}$ & $\begin{array}{l}.657 \\
.582\end{array}$ & $\begin{array}{l}.133 \\
.100\end{array}$ & $\begin{array}{r}2.14 \\
.67\end{array}$ & $\begin{array}{l}5 \\
4\end{array}$ & $\begin{array}{l}46 \\
37\end{array}$ & $\begin{array}{l}16 \\
20\end{array}$ & $\begin{array}{l}2.4 \\
5.8\end{array}$ & $\begin{array}{r}1.25 \\
.46\end{array}$ & $\begin{array}{l}14.7 \\
10.9\end{array}$ \\
\hline CWG-163 & $\begin{array}{l}\text { Jun } 30 \\
\text { Sep } 15\end{array}$ & $\begin{array}{r}15.1 \\
6.8\end{array}$ & $\begin{array}{l}.25 \\
.08\end{array}$ & $\begin{array}{l}.12 \\
.09\end{array}$ & $\begin{array}{l}.510 \\
.579\end{array}$ & $\begin{array}{l}.127 \\
.108\end{array}$ & $\begin{array}{r}1.96 \\
.51\end{array}$ & $\begin{array}{r}23 \\
3\end{array}$ & $\begin{array}{l}20 \\
36\end{array}$ & $\begin{array}{l}18 \\
14\end{array}$ & $\begin{array}{l}2.0 \\
7.2\end{array}$ & $\begin{array}{r}1.40 \\
.34\end{array}$ & $\begin{array}{l}16.4 \\
11.4\end{array}$ \\
\hline Fairway-128 & $\begin{array}{l}\text { Jun } 30 \\
\text { Sep } 15\end{array}$ & $\begin{array}{r}15.2 \\
7.6\end{array}$ & $\begin{array}{l}.28 \\
.10\end{array}$ & $\begin{array}{l}.11 \\
.10\end{array}$ & $\begin{array}{l}.477 \\
.481\end{array}$ & $\begin{array}{l}.132 \\
.102\end{array}$ & $\begin{array}{r}2.26 \\
.71\end{array}$ & $\begin{array}{l}6 \\
3\end{array}$ & $\begin{array}{l}21 \\
30\end{array}$ & $\begin{array}{l}16 \\
14\end{array}$ & $\begin{array}{l}1.7 \\
4.8\end{array}$ & $\begin{array}{r}1.67 \\
.56\end{array}$ & $\begin{array}{l}22.2 \\
12.1\end{array}$ \\
\hline RS Hybrid & $\begin{array}{l}\text { Jun } 30 \\
\text { Sep } 15\end{array}$ & $\begin{array}{r}11.5 \\
7.3\end{array}$ & $\begin{array}{l}.25 \\
.13\end{array}$ & $\begin{array}{l}.10 \\
.10\end{array}$ & $\begin{array}{l}.321 \\
.384\end{array}$ & $\begin{array}{l}.117 \\
.130\end{array}$ & $\begin{array}{l}2.47 \\
1.46\end{array}$ & $\begin{array}{l}5 \\
6\end{array}$ & $\begin{array}{l}26 \\
35\end{array}$ & $\begin{array}{l}21 \\
12\end{array}$ & $\begin{array}{l}1.3 \\
3.0\end{array}$ & $\begin{array}{l}2.46 \\
1.25\end{array}$ & $\begin{array}{l}18.4 \\
11.7\end{array}$ \\
\hline Nordan & $\begin{array}{l}\text { Jun } 30 \\
\text { Sep } 15\end{array}$ & $\begin{array}{r}16.7 \\
7.5\end{array}$ & $\begin{array}{l}.27 \\
.10\end{array}$ & $\begin{array}{l}.16 \\
.10\end{array}$ & $\begin{array}{l}.616 \\
.600\end{array}$ & $\begin{array}{l}.145 \\
.124\end{array}$ & $\begin{array}{r}2.25 \\
.57\end{array}$ & $\begin{array}{l}5 \\
3\end{array}$ & $\begin{array}{l}45 \\
45\end{array}$ & $\begin{array}{l}20 \\
12\end{array}$ & $\begin{array}{l}2.3 \\
6.0\end{array}$ & $\begin{array}{r}1.35 \\
.36\end{array}$ & $\begin{array}{l}16.7 \\
12.0\end{array}$ \\
\hline CWG-(M34-38) & $\begin{array}{l}\text { Jun } 30 \\
\text { Sep } 15\end{array}$ & $\begin{array}{r}15.1 \\
6.8\end{array}$ & $\begin{array}{l}.24 \\
.08\end{array}$ & $\begin{array}{l}.14 \\
.10\end{array}$ & $\begin{array}{l}.558 \\
.606\end{array}$ & $\begin{array}{l}.151 \\
.109\end{array}$ & $\begin{array}{r}2.07 \\
.46\end{array}$ & $\begin{array}{r}12 \\
4\end{array}$ & $\begin{array}{l}26 \\
41\end{array}$ & $\begin{array}{l}22 \\
17\end{array}$ & $\begin{array}{l}2.3 \\
7.6\end{array}$ & $\begin{array}{r}1.32 \\
.30\end{array}$ & $\begin{array}{l}17.2 \\
10.9\end{array}$ \\
\hline CWG-R & $\begin{array}{l}\text { Jun } 30 \\
\text { Sep } 15\end{array}$ & $\begin{array}{r}15.5 \\
7.5\end{array}$ & $\begin{array}{l}.32 \\
.10\end{array}$ & $\begin{array}{l}.16 \\
.12\end{array}$ & $\begin{array}{l}.661 \\
.604\end{array}$ & $\begin{array}{l}.185 \\
.156\end{array}$ & $\begin{array}{r}2.05 \\
.65\end{array}$ & $\begin{array}{l}5 \\
7\end{array}$ & $\begin{array}{l}45 \\
43\end{array}$ & $\begin{array}{l}14 \\
11\end{array}$ & $\begin{array}{l}2.1 \\
6.0\end{array}$ & $\begin{array}{r}1.09 \\
.39\end{array}$ & $\begin{array}{l}15.5 \\
10.0\end{array}$ \\
\hline Tall Fescue & $\begin{array}{l}\text { Jun } 30 \\
\text { Sep } 15\end{array}$ & $\begin{array}{r}13.8 \\
8.4\end{array}$ & $\begin{array}{l}.32 \\
.12\end{array}$ & $\begin{array}{l}.13 \\
.12\end{array}$ & $\begin{array}{l}.446 \\
.545\end{array}$ & $\begin{array}{l}.217 \\
.263\end{array}$ & $\begin{array}{l}3.49 \\
1.69\end{array}$ & $\begin{array}{l}5 \\
4\end{array}$ & $\begin{array}{l}68 \\
51\end{array}$ & $\begin{array}{l}15 \\
12\end{array}$ & $\begin{array}{l}1.4 \\
4.5\end{array}$ & $\begin{array}{r}2.23 \\
.89\end{array}$ & $\begin{array}{l}17.0 \\
11.2\end{array}$ \\
\hline Bozoisky-Select & $\begin{array}{l}\text { Jun } 30 \\
\text { Sep } 15\end{array}$ & $\begin{array}{l}17.6 \\
13.2\end{array}$ & $\begin{array}{l}.29 \\
.16\end{array}$ & $\begin{array}{l}.11 \\
.14\end{array}$ & $\begin{array}{l}.490 \\
.600\end{array}$ & $\begin{array}{l}.231 \\
.287\end{array}$ & $\begin{array}{l}3.38 \\
2.17\end{array}$ & $\begin{array}{l}5 \\
4\end{array}$ & $\begin{array}{l}26 \\
30\end{array}$ & $\begin{array}{l}20 \\
16\end{array}$ & $\begin{array}{l}1.7 \\
3.8\end{array}$ & $\begin{array}{l}1.99 \\
1.04\end{array}$ & $\begin{array}{l}25.6 \\
15.1\end{array}$ \\
\hline RWR-V13 & $\begin{array}{l}\text { Jun } 30 \\
\text { Sep } 15\end{array}$ & $\begin{array}{l}13.6 \\
12.6\end{array}$ & $\begin{array}{l}.29 \\
.17\end{array}$ & $\begin{array}{l}.12 \\
.13\end{array}$ & $\begin{array}{l}.525 \\
.629\end{array}$ & $\begin{array}{l}.218 \\
.294\end{array}$ & $\begin{array}{l}3.13 \\
1.99\end{array}$ & $\begin{array}{l}7 \\
3\end{array}$ & $\begin{array}{l}32 \\
69\end{array}$ & $\begin{array}{l}19 \\
18\end{array}$ & $\begin{array}{l}1.8 \\
3.7\end{array}$ & $\begin{array}{r}1.81 \\
.92\end{array}$ & $\begin{array}{l}18.1 \\
15.5\end{array}$ \\
\hline RWR-128 & $\begin{array}{l}\text { Jun } 30 \\
\text { Sep } 15\end{array}$ & $\begin{array}{r}16.8 \\
8.2\end{array}$ & $\begin{array}{l}.28 \\
.15\end{array}$ & $\begin{array}{l}.13 \\
.12\end{array}$ & $\begin{array}{l}.644 \\
.683\end{array}$ & $\begin{array}{l}.255 \\
.275\end{array}$ & $\begin{array}{l}3.43 \\
1.92\end{array}$ & $\begin{array}{l}5 \\
2\end{array}$ & $\begin{array}{l}30 \\
57\end{array}$ & $\begin{array}{l}26 \\
18\end{array}$ & $\begin{array}{l}2.3 \\
4.6\end{array}$ & $\begin{array}{r}1.65 \\
.87\end{array}$ & $\begin{array}{l}20.6 \\
10.9\end{array}$ \\
\hline
\end{tabular}

Potassium and $\mathrm{K}:(\mathrm{Ca}+\mathrm{Mg})$ Ratio

The potassium levels of the 10 Agropyron-Elytrigia accessions are adequate for cattle and sheep during the spring and summer, but declined to levels at or below the recommended $0.6-0.8 \%$ of the ration dry matter in the late summer and fall. Tall fescue and the 3 Russian wildrye accessions contained sufficient potassium throughout the period.

High levels of potassium in the spring and generally lower levels of calcium and magnesium give rise to high ratios of $\mathrm{K}:(\mathrm{Ca}+\mathrm{Mg})$.
Kemp and t'Hart (1957) indicate that when the ratio, expressed on an equivalence basis, is greater than 2.2:1 the incidence of grass tetany also increases dramatically. Both RS-hybrid and tall fescue had ratios above 2.2:1 on June 30 . However, the blood serum magnesium level, a criterion for proneness to grass tetany (Mayland and Grunes 1979), indicates that all accessions were safe to graze on June 30. Murray et al. (1978) found the ratio declined with plant maturity suggesting that earlier in the spring the ratio may well be above 2.2:1 for many of the accessions.

Table 5. Rated use of plots and rated numbers of seedstalks following grazing by sheep in mid-May, mid July, and mid-September, 1980 for 14 accessions outplanted at the U.S. Sheep Experiment Station, Dubois, Idaho.

\begin{tabular}{|c|c|c|c|c|c|c|}
\hline \multirow[b]{2}{*}{ Accession } & \multicolumn{2}{|c|}{ May 14} & \multicolumn{2}{|c|}{ July 14} & \multicolumn{2}{|c|}{ September 15} \\
\hline & Use & Seedstalks & Use & Seedstalks & Use & Seedstalks \\
\hline $\begin{array}{l}\text { Crested Wheatgrass or } \\
\text { CWG Hybrid }\end{array}$ & 2.1 & 7.5 & 0.8 & 8.2 & 1.1 & 8.8 \\
\hline CWG-(V6-7) & 2.2 & 6.9 & 0.3 & 7.3 & 1.6 & 8.6 \\
\hline Fairway & 1.9 & 6.7 & 1.1 & 7.5 & 1.7 & 7.6 \\
\hline Siberian WG & 2.2 & 6.7 & 0.9 & 7.5 & 1.5 & 7.9 \\
\hline CWG-I63 & 1.8 & 6.6 & 1.8 & 6.7 & 2.9 & 6.9 \\
\hline Fairway-128 & 2.7 & 7.0 & 1.3 & 7.3 & 3.0 & 7.6 \\
\hline RS Hybrid & 4.6 & 4.4 & 5.7 & 4.2 & 6.2 & 3.9 \\
\hline Nordan & 4.3 & 5.8 & 0.5 & 7.5 & 1.2 & 7.9 \\
\hline CWG-(M34-38) & 2.0 & 6.9 & 0.9 & 7.1 & 1.8 & 7.3 \\
\hline CWG-R & 2.2 & 5.8 & 1.6 & 6.8 & 1.4 & 6.9 \\
\hline Tall Fescue & 5.1 & 3.2 & 8.3 & 3.1 & 9.1 & 2.2 \\
\hline Bozoisky-Select & 7.0 & 2.5 & 7.9 & 1.9 & 9.6 & 0.5 \\
\hline RWR-V13 & 7.5 & 2.4 & 8.7 & 1.9 & 9.6 & 0.4 \\
\hline RWR-128 & 7.2 & 2.4 & 8.7 & 1.7 & 9.7 & 0.3 \\
\hline
\end{tabular}




\section{Copper, Manganese, and Zinc Contents}

Copper levels in forage of all accessions, except Fairway, were adequate ( $>4-5 \mathrm{ppm}$ ) for cattle and sheep on June 30 , but were inadequate in 10 of the 14 accessions on September 15. Should the accessions be planted on sites where high uptakes of molybdenum might occur, a copper deficiency in animals could be induced even when the copper content is quite high. Also, when copper levels fall below normal or the sulfate level is high, molybdenum uptake as low as 1-2 ppm may be toxic (NRC-NAS, 1975).

The manganese levels in forage were greater than the recommended $1-10 \mathrm{ppm}$ for cattle in all accessions on both dates. Dietary levels of manganese are not known for sheep, but the levels reported here are most likely adequate.

In general, zinc levels were adequate for cattle and sheep, but were below levels considered to be adequate for cattle and sheep after June 30. A decline in zinc content with advance in season is common for most grasses (Murray et al. 1978). Supplementation of zinc has increased cow and calf gains on zinc deficient forage (Mayland 1975).

\section{Preference of the Accessions by Sheep}

An important attribute for determining the value of a species is its palatability. If the species is to be used for forage then the species must be used by the animals. The 14 accessions were evaluated at 3 dates in 1980 for their relative palatability by allowing sheep to graze "free-choice" and then rating the degree of use.

The use of wheatgrasses, except the RS-hybrid, declined in July and increased slightly in September compared to May grazing (Table 5). Use of the hybrid increased steadily with the advance in season. A similar increase in use occurred for tall fescue and the 3 Russian wildrye accessions. These 5 accessions were probably preferred because they produced fewer seedstalks than the other accessions and tended to remain green longer.

A regression analysis was performed to test whether use was influenced by the amount of seedstalks. The results clearly indicate that an increase in the numbers of seedstalks reduces the use (Fig. 1). Sheep grazed strips clipped the previous September at a much heavier rate because they were not hindered by as many seedstalks. Evaluation of these rates showed that there was little difference in the palatability of the various accessions in the grazed strips.

\section{Effect of Burning on Seedstalk Production}

Since utilization decreased with an increase in numbers of seedstalks, it was hypothesized that burning early in the spring, before growth commenced, would remove the old, standing dead seedstalks, and other litter, and might reduce the numbers of seedstalks produced in the current year.

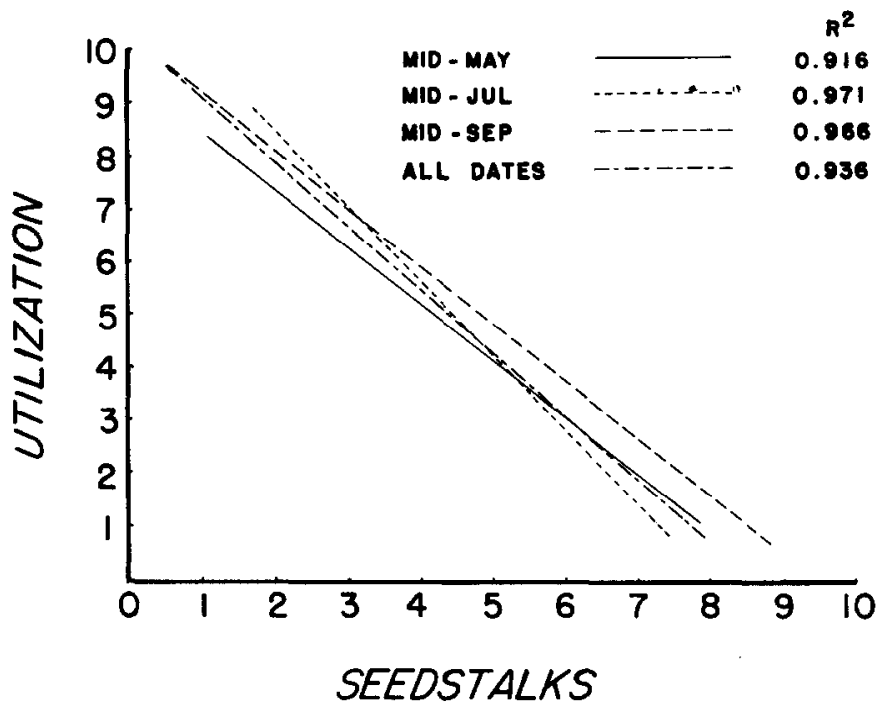

Fis. 1. Relationship between the rated utilization by sheep and the rated number of seedstalks for 14 accessions at 3 dates during 1980.

Burning early in the spring (mid-March 1981), at least 3 weeks before growth began, removed all of the dead plant material and did not inhibit subsequent growth. Although, there was considerable variation in the number of seedstalks between subplots within the nonburned and burned plots, the data suggest that burning tends to stimulate seedstalk production in most of these accessions (Table 6).

Removal of the standing dead material by burning should encourage greater early use of the accessions. Heavy grazing in the spring, following burning, may also reduce the number of seedstalks by removing flower primordia. Hyder and Sneva (1963) discuss more fully the implications of the morphological and physiological factors that affect grazing management of crested wheatgrass.

An index based on leaf yields, crude leaf protein content, and sheep preference gave the following ranking: (1) Bozoisky-Select, (2) RWR-V13, (3) RWR-I28, (4) Tall fescue, (5) RS hybrid, (6) Fairway I28, (7) Nordan, (8) CWG-163), (9) Fairway, (10) CWGR, (11) GWG (M34-38), (12) Siberian WG, (13) CWG (V6-7), and (14) CWG-hybrid (Table 7). Although the index was developed

Table 6. Mean number of seedstalks per $m$ of row, standard error of the mean, and significant differences of means for non-burned and burned wheatgrass accessions as measured on July 21, 1981 at the U.S. Sheep Experiment Station, Dubois, Idaho.

\begin{tabular}{|c|c|c|c|c|c|c|}
\hline \multirow[b]{2}{*}{ Accession } & \multirow[b]{2}{*}{ No. subplots } & \multicolumn{2}{|c|}{ Non-burned } & \multicolumn{2}{|c|}{ Burned } & \multirow[b]{2}{*}{$\mathrm{t}$} \\
\hline & & Mean & S.E. & Mean & S.E. & \\
\hline \multicolumn{7}{|c|}{ Crested wheatgrass or } \\
\hline CWG Hybrid & 18 & 25.9 & 4.6 & 45.2 & 13.4 & $-2.14^{*}$ \\
\hline CWG-(V6-7) & 18 & 75.3 & 14.2 & 66.0 & 20.5 & .49 \\
\hline Fairway & 18 & 25.7 & 5.8 & 42.3 & 12.7 & -1.76 \\
\hline Siberian WG & 18 & 64.0 & 10.6 & 74.0 & 24.2 & -.52 \\
\hline CWG-I63 & 18 & 46.3 & 9.4 & 47.8 & 13.5 & -.12 \\
\hline Fairway-128 & 12 & 30.3 & 7.5 & 40.5 & 13.3 & -1.11 \\
\hline RS Hybrid & 12 & 17.5 & 2.7 & 24.1 & 8.4 & -1.29 \\
\hline Nordan & 18 & 50.9 & 7.1 & 58.3 & 16.0 & -.73 \\
\hline CWG-(M34-38) & 18 & 45.4 & 5.9 & 83.8 & 24.3 & -.52 \\
\hline CWG-R & 18 & 27.2 & 4.8 & 54.5 & 16.5 & $-2.03 *$ \\
\hline
\end{tabular}

$*=P<.05$ 
Table. 7. Index value and ranking of 14 accessions outplanted at the U.S. Sheep Experiment Station based on the sum of the percent of the largest leaf yield in late August, 1983, percent of the largest leaf crude protein contents (June 30 and September 15, 1978), and the percent of the greatest rated sheep use (May 14 + July 14 + September 15, 1980.

\begin{tabular}{|c|c|c|c|c|c|}
\hline Accession & Leaf $\%$ & $\begin{array}{c}\text { Crude } \\
\text { Protein \% }\end{array}$ & $\begin{array}{l}\text { Rated } \\
\text { Use \% }\end{array}$ & Index & Rank \\
\hline CWG-Hybrid & 28 & 66 & 16 & 110 & 14 \\
\hline CWG-(V6-7) & 22 & 79 & 16 & 117 & 13 \\
\hline Fairway & 38 & 72 & 18 & 128 & 9 \\
\hline Siberian WG & 33 & 67 & 18 & 118 & 12 \\
\hline CWG-I63 & 36 & 71 & 25 & 132 & 8 \\
\hline Fairway I28 & 33 & 74 & 27 & 134 & 6 \\
\hline RS Hybrid & 50 & 61 & 64 & 175 & 5 \\
\hline Nordan & 32 & 79 & 23 & 134 & 7 \\
\hline CWG-(M34-38) & 36 & 71 & 18 & 125 & 11 \\
\hline CWG-R & 30 & 75 & 20 & 125 & 10 \\
\hline Tall Fescue & 93 & 72 & 87 & 252 & 4 \\
\hline Bozoisky-Select & 100 & 100 & 95 & 295 & 1 \\
\hline RWR-V13 & 99 & 85 & 100 & 284 & 2 \\
\hline RWR-128 & 98 & 82 & 99 & 279 & 3 \\
\hline
\end{tabular}

primarily for assessing the value for sheep, systems for ranking for other purposes can be derived from the data presented

\section{Conclusions}

The 14 accessions outplanted at the U.S. Sheep Experiment Station were well adapted to the climate of the Upper Snake River Plains. Time of germination varied between accessions, but by early May all had germinated and all were well established by late June. Total production of the wheatgrasses was greater than production of tall fescue and the 3 Russian wildrye accessions. The increased production was due to a greater proportion of flowering stems compared to leaf and vegetative stems. Sheep use was proportionately reduced with an increase in numbers of seedstalks, but all accessions were nearly equally palatable when seedstalks were not a factor.

Crude protein contents in leaves of all accessions declined with plant maturity. However, 2 Russian wildryes (Bozoisky select and RWR-V13) had crude protein contents above $12 \%$ in midSeptember compared to the $7.4 \%$ average for all wheatgrasses. Russian wildryes tend to remain greener longer than wheatgrasses and may have responded to the favorable precipitation during early September 1978. Minerals were adequate for cattle and sheep during the period when leaves were green, but phosphorus, sulfur, potassium, copper, and zinc dropped below levels considered adequate in most accessions by mid-September.

Sheep preference for the 14 accessions appeared to be inversely related to the number of seedstalks produced. Those accessions such as CWG-I63 producing a large number of seedstalks were used less at all dates compared to accessions such as the Russian wildryes, which produced few seedstalks. When seedstalks were removed by clipping the previous fall preference for all accessions was similar.

Early spring burning before leaf growth began was effective for removing dead standing seedstalks and accumulated litter, but did not reduce the numbers of new seedstalks produced. Occasional burning in the early spring followed by heavy grazing to remove floral primordia may be effective for reducing the number of seedstalks of wheatgrasses and thus encourage greater sheep use in the fall.
The overall value of the 14 accessions for sheep was determined by an index based on leaf weights, crude protein contents, and rated use. The Russian wildrye "Bozoisky" and RWR-V13 ranked 1 and 2, while the wheatgrasses (CWG-(V6-7) and CWG-hybrid were ranked thirteenth and fourteenth, respectively. Although, most wheatgrasses produced greater biomass than the Russian wildryes, tall fescue, and the RS-Hybrid much of the weight was associated with the seedstalk + head fraction. This fraction is not used by sheep to any great extent and appears to discourage use. Species which are leafy and remain green longer are preferred by sheep. Consequently, one of the objectives for grass genetics research for improving species for sheep in semi-arid regions should be to develop grasses which have a high proportion of leaf to stems, remain photosynthetically active longer, are drought and disease resistant, and are highly productive.

\section{Literature Cited}

Allaway, W.H. 1969. Trends in the mineral composition of feeds. Proc. Cornell Nutr. Conf. for Feed Manuf., Oct. 21-23, Buffalo, N.Y.

Bremner, J.N. 1965. Total nitrogen. p. 1149-1178. In: Methods of Soil Analysis, Pt. 2. Chemical \& Microbiological Properties. Amer. Soc. Agron.

Bureau of Land Management. 1974. Idaho Range Management Progress Rep. p I-6-I-7.

Dewey, D.R. and K.H. Asay. 1975. The crested wheatgrasses of Iran. Crop Sci. 15:844-849.

Drawe, D.L., and Palmblad. 1977. Competition between Russian wildrye seedlings and four common weeds. J. Range Manage. 30:223-226.

Greweling, T. 1976. Chemical Analysis of Plant Tissue. Cornell Univ. Agr. Exp. Sta. Vol. 6 No. 8. Ithaca, N.Y.

Hyder, D.N., and A. Sneva. 1963. Morphological and physiological factors affecting the grazing management of crested wheatgrass. Crop Sci. 3:267-271.

Kemp, A., and M.L. t'Hart. 1957. Grass tetany in grazing milking cows. Neth. J. Agr. Sci. 5:4-17.

Lodge, R.W. 1963. Complementary grazing systems for Sandhills of the Northern Great Plains. J. Range Manage. 16:240-244.

Lodge, R.W., S. Smoliak, and A. Johnston. 1972. Managing crested wheatgrass pastures. Canada Dep. Agr. Pub.

Mayland, H.F. 1975. Zinc increases range cattle weight gains. J. Anim. Sci. 4:337 (Abstract).

Mayland, H.F., and D.L. Grunes. 1979. Soil-climate-plant relationships in the etiology of grass tetany, p. 123-175. In: V.V. Rendig and D.L. Grunes (eds) Grass Tetany. Amer. Soc. Agron. Soc., Madison, Wis.

Murray, R.B., H.F. Mayland, and P.J. Van Soest. 1978. Growth and nutritional value to cattle of grasses on cheatgrass range in southern Idaho. USDA-FS Res. Pap. INT-199.

National Research Council-National Academy of Sciences. 1970. Nutrient requirements of beef cattle. Number 4 .

National Research Council-National Academy of Sciences. 1975. Nutrient requirements of sheep. Number 5 .

Reynolds, T.D., and C.H. Trost. 1980. The response of native vertebrate populations to crested wheatgrass planting and grazing by sheep. $J$. Range Manage. 32:122-125.

Rogler, G.A., and L.J. Lorenz. 1970. Beef production from Russian wildrye (Elymus junceus Fisch.) in the United States. Proc. XI. Int. Grassland Congr. 835-838.

Sarvis, J.T. 1941. Grazing investigations on the Northern Great Plains. N. Dak. Agr. Exp. Sta. Bull. 308.

Smoliak S. 1968. Grazing studies on native range, crested wheatgrass, and Russian wildrye pastures. J. Range Manage. 21:47-50.

Smoliak, S., and S.B. Slen. 1974. Beef production on native range, crested wheatgrass, and Russian wildrye pastures. J. Range Manage. 27:433-436.

Perez-Trejo, F., D.D. Dwyer, and K.H. Asay. 1979. Forage yield, phenological development, and forage quality of an Agropyron repens $\times$ A. spicatum Hybrid. J. Range Manage. 32:387-390. 